研究

\title{
金属液体の多段階粉砕技術の開発と急速凝固球状微細粉末の作製
}

\author{
王新敏, 井上 明久
}

東北大学金属材料研究所, 干 980-8577 仙台市青葉区片平 2-1-1.

\section{Development of Multistage Pulverization Technique for Metallic Liquids and Production of Rapidly Solidified Spherical Metallic Powders with Fine Sizes}

\author{
XinMin Wang and Akihisa Inoue \\ Institute for Materials Research, Tohoku University, 2-1-1 Katahira Aoba-ku, Sendai 980-8577, Japan.
}

Received June 29, 2006

\section{SYNOPSIS}

In this technique, gas-atomization was used at the first stage to produce alloy powders with molten metal. subsequently the atomized alloy powders are flown down, and then crushed into a vapidly notating disk with a high speed of about $250 \mathrm{~m} / \mathrm{s}$. Non-solidified and half solidified alloy powders were broken to the smaller ones. According to this mechanism, the further subsequent crash is likely to occur for the remaining non-solidified and half solidified alloy powders.

This non-solidified and half solidified alloy powders can be broken to fine powders one by through the multistage crush mechanism.

In this method, the size of fine powders could be controlled by changing the temperature and flux of molten metal, flux of gas, tangential velocity of rotating disk, distance between disk and nozzle for molten metal, flux of cooling media, and so on. Furthermore, the powders are flown and rotated simultaneously by the rapidly circumrotating disk, The unique mechanism rsuets in the production of spherical powders. In the case of producing $\mathrm{Cu}$ powders. The first stage gas atomization, $40 \mu \mathrm{m}$ diameter powders are obtained by the first stage second crush on the rapidly circumrotating disk can produce $10 \mu \mathrm{m}$ powders. Similarly, We also confirmed the production of fine $7 \mu \mathrm{m} \mathrm{Al}$ powders. These fine spherical powders, can have various nonequilibrium phases such as nanocrystalline and amorphous phases owing to high cooling rates.

\section{KEY WORDS}

atomization, multistage pulverization, rapidly solidified, metallic powders

\section{1 諸 言}

複雑形状の金属部品の成形技術として注目されている粉末 射出成形用や自動車塗料用などの金属粉末には平均粒径 10 $\mu \mathrm{m}$ の微細粉末が要求されている ${ }^{1,2)}$.また, 粉末冶金製品の 組織の緻密性や流動性を向上させるために, 原料粉末の球状 化が要望されてきた ${ }^{3,4}$. さらに, 新素材を開発するための素 材として重要であるナノ結晶や金属ガラスなどの非平衡組織 を有する微細粉末の大量生産技術の開発が強く求められてい る ${ }^{5,6)}$. しかし, 現時点で低コスト, 高流動性, 平均粒径 $10 \mu \mathrm{m}$ の非平衡球状微粉末の生産技術は無く, 微細粉末は分級や粉 砕により得られており, 量的, 質的および効率的にも問題を 抱えている.
我々のグループは合金液体の多段階粉砕方法を利用して, 非平衡相をもち, 球状で, しかも, 平均粒径 $10 \mu \mathrm{m}$ の微粉末 を大量に作製できる技術の確立を目指した研究を行ってきた. 本方法では, 第一段階のガスアトマイズ噴霧法で溶湯を粉砕 した後, 飛翔中未凝固粉末或いは溶湯液滴粒子は, ガスアト マイズノズルの直下に設置した回転体の衝撃力により第二段 階目として粉砕される. その後においても未凝固状態の液滴 があれば，回転体の外側に設置した傘型ロールにより第三段 階目として粉砕する方法であり，これを金属液体の多段階粉 砕法と名づけ, 非平衡な金属微細球状粉末の作製技術の開発 を目指している。

凝固中の粒子は回転体に衝突後, 回転体の接線方向へ自転 
しながらその表面に沿って飛散するため, 球状となりやすい. また, 粉砕された微細粉末は従来の粗大粉末より熱が散発し やすく, 急冷効果があるため, ナノ結晶やガラス相などの非 平衡組織となりやすい.

今日まで報告されている粉末製造法はガスアトマイズ, 水アトマイズ, 遠心アトマイズなどの単一段の粉砕方法であ る $^{7-10)}$. 多段階粉砕方法で球状粉末を作製する技術は未だ報 告されていない，そこで，本研究では，新しい多段階粉砕技 術を開発することにより, 平均粒径 $10 \mu \mathrm{m}$ の急速凝固球状微 細粉末の作製とその粉末の特徵を検討することを目的として いる.

\section{2 実験方法}

本研究で開発した装置の概略図をFig.1に示す. 本装置の特 徵として, ガスアトマイズの溶湯ノズル直下に, 多段階粉䂶 用の衝突体として回転ディスクと回転傘ロールを設けている.

実験用試料は $\mathrm{Cu}, \mathrm{Al}, \mathrm{Co}, \mathrm{Zn}, \mathrm{Fe}$ などの純金属, $\mathrm{Fe}-\mathrm{Si}$-C-B 系アモルファス合金, ステンレス鋼, センダストなどである. 純金属とステンレス鋼は市販の試薬品を購入し, $\mathrm{Fe}-\mathrm{Si}-\mathrm{C}-\mathrm{B}$ アモルファス合金はアーク溶解炉を用いて Arガス中で作製し た、噴霧ガスには窒素を使い, ガス圧力は $10 \mathrm{MPa}$ 以下であっ た. 坩堝の溶解量は最大 $1.0 \mathrm{~kg}$ であるが, 本実験では1チャー ジの溶解量を $0.5 \mathrm{~kg}$ とした. 溶解合金の出湯温度は融点より $100 \sim 300 \mathrm{~K}$ 高く設定した. 回転ディスク直径は $600 \mathrm{~mm}$ であ り，回転速度は $18000 \mathrm{rpm}$ までの範囲内で調節し，逆方向へ 回す回転ロールの回転速度は $200 \mathrm{rpm}$ までの範囲で調節する ことができる，回転ディスクはアルミニウム合金製であり， 溶湯ノズルから直下の 50-250 mm 幅の範囲で昇降し, 設置 位置は溶湯ノズルの中心から $250 \mathrm{~mm}$ の箇所に偏心させた. 回転ディスクの温度上昇を防止するため, 冷却水を用いた. 冷却水の流量は $55 \mathrm{~L} / \mathrm{min}$ までの範囲で調節した. 回転ディス クの設置距離は粉末の凝固時間と飛翔速度の計算結果および 冷却速度に基づいて決定した。

本方法で作製した粉末では, 脱水と乾燥の工程が必要であ る. 脱水は自然濾過式で, 乾燥は真空吸収法で行った。粉末

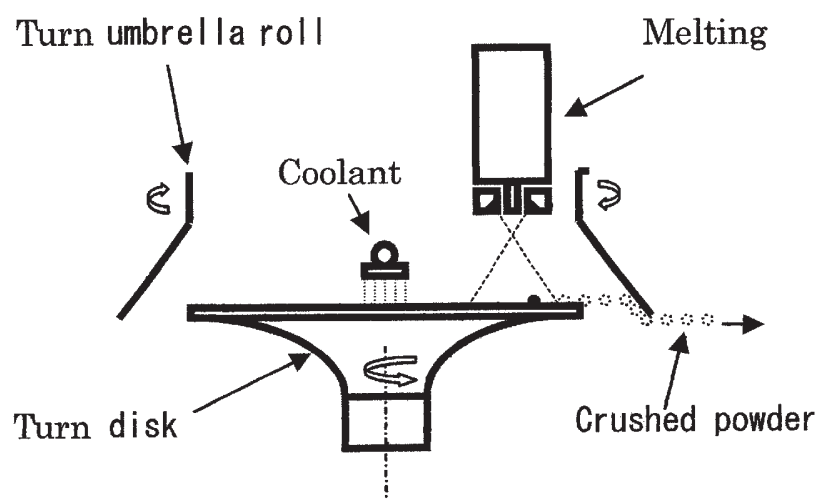

Fig.1 Schematic illustration of a multistage crush apparatus for metallic liquids.
の粒径, 粒状, 密度, 比表面積, 酸化度, 組織の評価は, そ れぞれレーザー回折・散乱式粒度分布測定装置, ガス吸着式 比表面積測定器, 酸素分析装置, X 線回折装置, および走査 電子顕微鏡を用いて行った.

\section{3 実験結果および考察}

本研究で開発した多段階急冷粉研装置におりる粉研原理を Fig.2に示す. 溶湯を一次ガスアトマイズ粉砕法で粉砕して得 た粉末には, 一定の距離内で凝固した小粒子, 半溶融の中等 サイズの粒子および溶融状態の大粒子が混在している. 溶融 及び半溶融状態の未凝固粒子を標的にして, 回転ディスクお よび金型ロールにより再粉砕することが本研究の鍵である. 本研究の粉砕法では, 噴霧ガスの粉砕力と回転体の衝撃力と の粉硒バランス調整は非常に重要である. 第一段目で大きい 噴霧圧力で十分に粉砝すれば, 一定の距離内で溶融粒子が凝 固を完了してしまい, 回転体の衝撃力をいくら大きくしても 無䭾となる. 逆に, 溶融粒子のサイズが大きく, 量も多い場 合には, 衝撃力が不足することになる．また，大粒径の溶融 粒子は多くの熱を持っているので, 回転体表面で堆積する可 能性がある. そこで, 再粉砕を充分に達成するためには, 溶 湯の粉砕により生成される粒子の運動学を理論的に解明する 必要がある. 実験上で回転ディスク表面までの未凝固粒子の 量, 回転ディスクの衝撃力および回転体表面への影響を明ら かにしなければならない. 本研究では純Cuを用いて, 溶湯の 粒子化の運動学による解析を試みた。

ガスアトマイズ粉末の凝固時間 $\mathrm{t}$ は次のように見積られて いる ${ }^{11)}$.

$$
t=\frac{D \rho_{d}}{6 \beta}\left[C_{p} \ln \left(\frac{T_{m}-T_{0}}{T_{s}-T_{0}}\right)+\frac{\Delta H_{s}}{T_{s}-T_{0}}\right]
$$

ここで, 融点 $T_{s}: 1356 \mathrm{~K}$, 密度 $\rho_{d}: 8.94 \mathrm{~g} / \mathrm{m}^{3}$, 熱容量 $C_{p}: 24 \mathrm{~J} /$

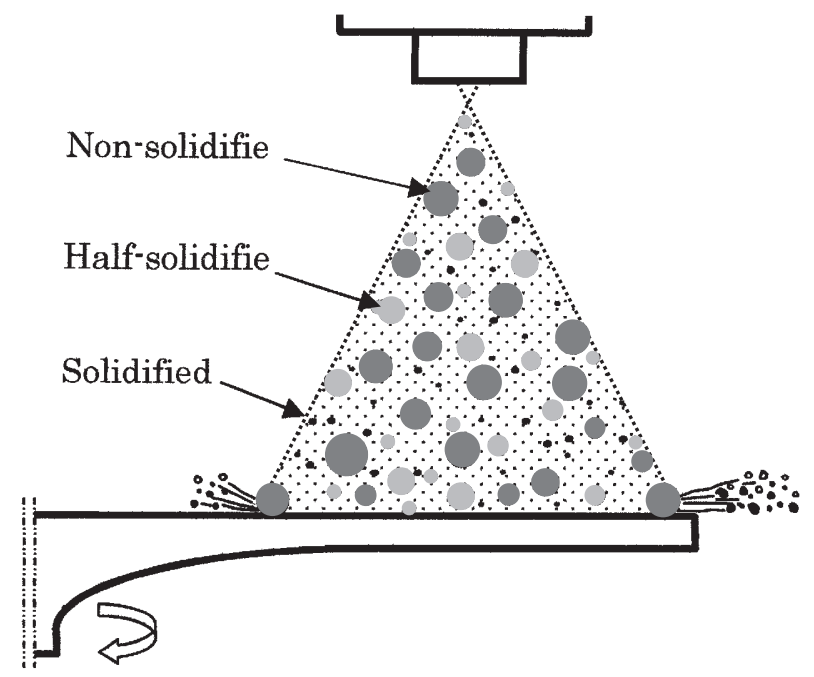

Fig.2 Schematic illustration of crush mechanism for metallic liquids in the multistage crush method. 
$\mathrm{mol}$, ガスの温度 $T_{0}: 298 \mathrm{~K}$, 溶湯温度 $T_{m}: 1356 \mathrm{~K}$, 融解熱 $\Delta H_{s}$ : $13 \mathrm{~J} / \mathrm{mol}$, 熱伝達係数 $\beta:(\mathrm{x}) \mathrm{J} / \mathrm{m}^{2} \mathrm{sK}, \mathrm{D}$ : 粒子直径であり, 式 中の熱伝達係数 $\beta$ は次式 ${ }^{12)}$ により求められる.

$$
\beta=\frac{\lambda}{D} N_{u}
$$

ガスの熱伝導率 $\lambda$ (窒素の場合 $\mathrm{N}_{2}=0.024 \mathrm{kcal} / \mathrm{mh}^{\circ} \mathrm{C}$ ), ヌセ ルト数 $N_{u}$ は粉末を球状之仮定し, 自然対流伝達の場合, 次式 ${ }^{12)}$ より求められる.

$$
N_{u}=2+0.6 \operatorname{Pr}^{1 / 3}+R_{e}^{1 / 2}
$$

ブラントル数 $P_{r}: 0.71$, レイノルズ数 $R_{e}$ は次式 ${ }^{13)}$ より求め られる.

$$
R_{e}=\frac{v_{g} D}{\phi}
$$

D: 粒子直径 $\mathrm{mm}, v_{\mathrm{g}}$ ガス流速: $\mathrm{m} / \mathrm{s}$, ガスの動粘性係数 $\psi: 0.185$ $\mathrm{m}^{2} / \mathrm{s}$, ヌセルト数 $N_{u}$ とレイノルズ数 $R_{e}$ および粒子 Dの関係を Fig.3aに示す. 粒径 Dが増大すると共に, ヌセルト数 $N_{u}$ とレ イノルズ数 $R_{e}$ が増加する. 熱伝達係数 $\beta$, 凝固時間 $\mathrm{t}$ と粒径 D の関係を Fig.3b に示す.

ガス流速 $v_{g}$ は次式 ${ }^{14)}$ より求められる.

$$
\bar{v}_{g}=M_{1}\left(x R T_{0}\right)^{0.5}\left[1+\frac{x-1}{2} \cdot M_{1}^{2}\right]^{-0.5}
$$

$\mathrm{M}$ マッ八数は 1 〜 の範囲で変化する. $\mathrm{R}$ は気体定数, $T_{o}$ は

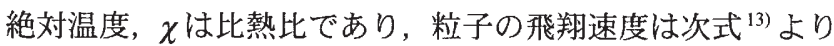
求められる。
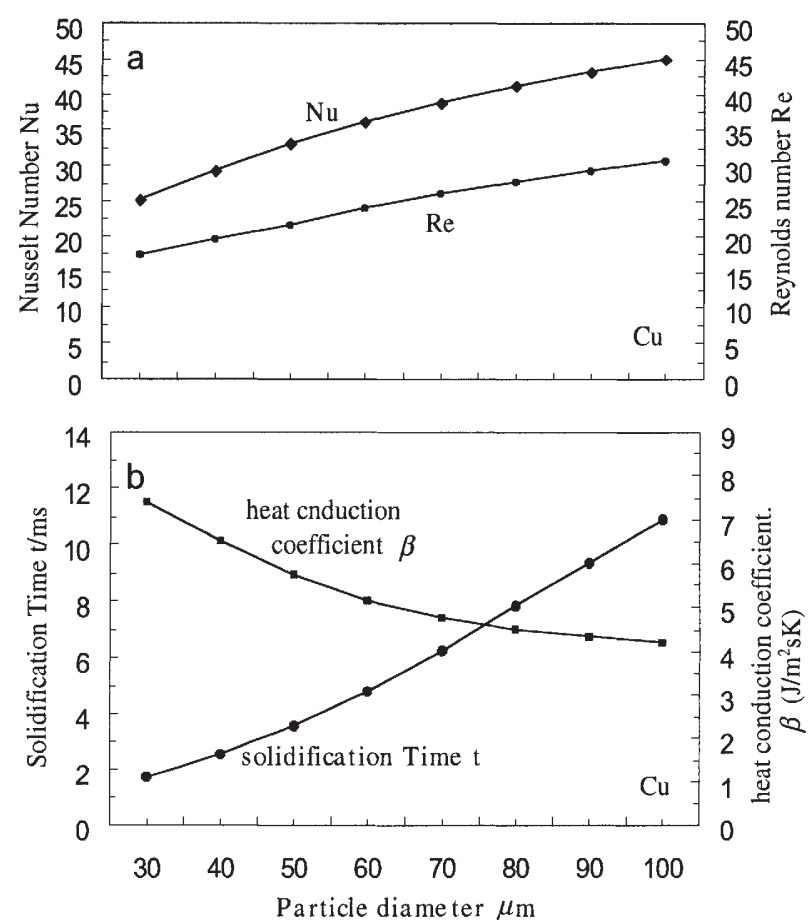

Fig3 Changes in the Nusselt number, Reynolds number, solidification time and heat conduction coefficient with particle diameter for $\mathrm{Cu}$ metallic liquid

$$
\begin{aligned}
\rho_{d} V_{d} \frac{d \overrightarrow{v_{d}}}{d t}=V_{d}\left(\rho_{d}-\rho_{g}\right) g \\
\quad+\left(A_{d} / 8\right) C_{d r a g} \rho_{g}\left(\bar{v}_{g}-\bar{v}_{d}\right)\left|\left(\bar{v}_{g}-v_{d}\right)\right|
\end{aligned}
$$

ここで, 粒子凝固時間 $\mathrm{t}: \mathrm{s}$, 粒子の飛翔速度 $v_{d}: \mathrm{m} / \mathrm{s}$, 融体密 度 $\rho_{d}: \mathrm{g} / \mathrm{cm}^{3}$, 加速度 $\mathrm{g}$, 粒子体積 $V_{d}$, 抵抗係数 $\mathrm{C}_{\mathrm{drag}}$, ガス密 度 $v_{g}$, 粒子の表面積 $A_{d}$ であり, 抵抗係数 $\mathrm{C}_{\mathrm{drag}}$ 注次式 ${ }^{13)}$ より求 める.

$$
C_{\text {drag }}=0.28+6 R_{e}^{0.5}+21 R_{e}
$$

以上の式によって計算したガスの流速と粒子の飛翔速度と の関係を Fig.4に示す．これにより，2MPaのガス圧力では， 直径 $30 \mu \mathrm{m}$ の粉末の凝固時間は $1.09 \mathrm{~ms}$ である.この時間で, $196 \mathrm{~mm}$ の所に到達すると見積もつた. 即ち, $196 \mathrm{~mm}$ 以内の 距離で直径 $30 \mu \mathrm{m}$ 以上の粒子はほとんど未凝固な溶融状態あ るいは半溶融状態で飛翔していると推測できる. $30 \mu \mathrm{m}$ 以上 の粉末を再粉砕することができれば, 非常にシャープな粒度 分布之細かい粒径の粒子が得られると考えられる. 実際には 回転円板体表面までの未凝固粒子の量は粒子の飛翔距離, 飛 翔速度以外に, 溶湯温度, 溶湯流量, 噴霧圧力, 周囲環境に よる粒子の冷却速度などの複雑な因子により影響されている

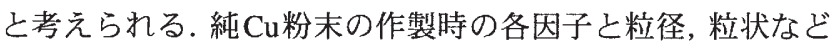
の物性の関係を Fig.5に示す。

3.1 溶湯温度と流量

一般にガスアトマイズ法では溶湯温度が高いほど, 溶湯の 粘性が減少するので, 粉末は細かくなることが知られている 17). 多段階粉砕方法は回転体の衝撃により再粉砕するため, 溶湯温度と粒径の関係は直線的ではなく, Fig.5aに示すよう に融点 $+200 \mathrm{~K}(\mathrm{Cu}$ の場合には $1500 \mathrm{~K})$ 以上の過熱温度では, $10 \mu \mathrm{m}$ 前後でほぼ一定となってしまい，これ以上細かくなら ないことが分かっている.この実験結果により, 溶湯温度が 高ければ未凝固の粒子が多くなるが, 回転ディスクの粉砕負 担が大きくなることおよび回転体表面に堆積する影響がある ため, 溶湯温度を単純に高くすることは微細化をもたらさな

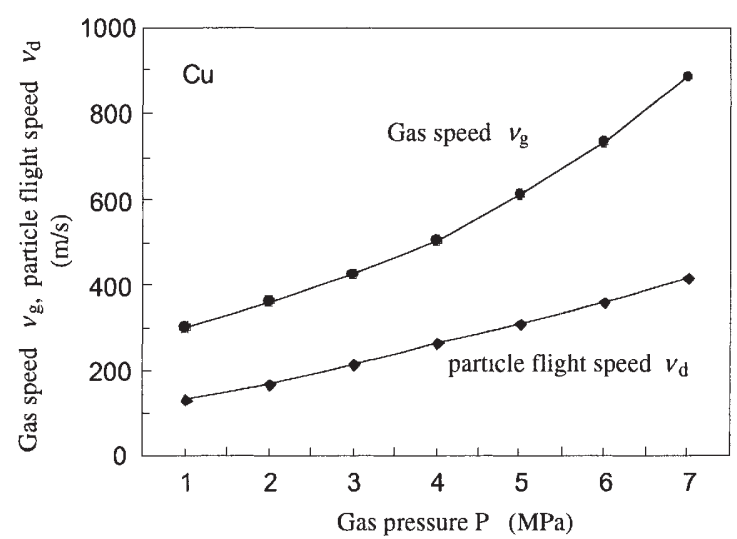

Fig.4 Gas speed $v_{\mathrm{g}}$ and particle flight speed $v_{\mathrm{d}}$ with gas pressure $\mathrm{P}$ for $\mathrm{Cu}$ liquid. 

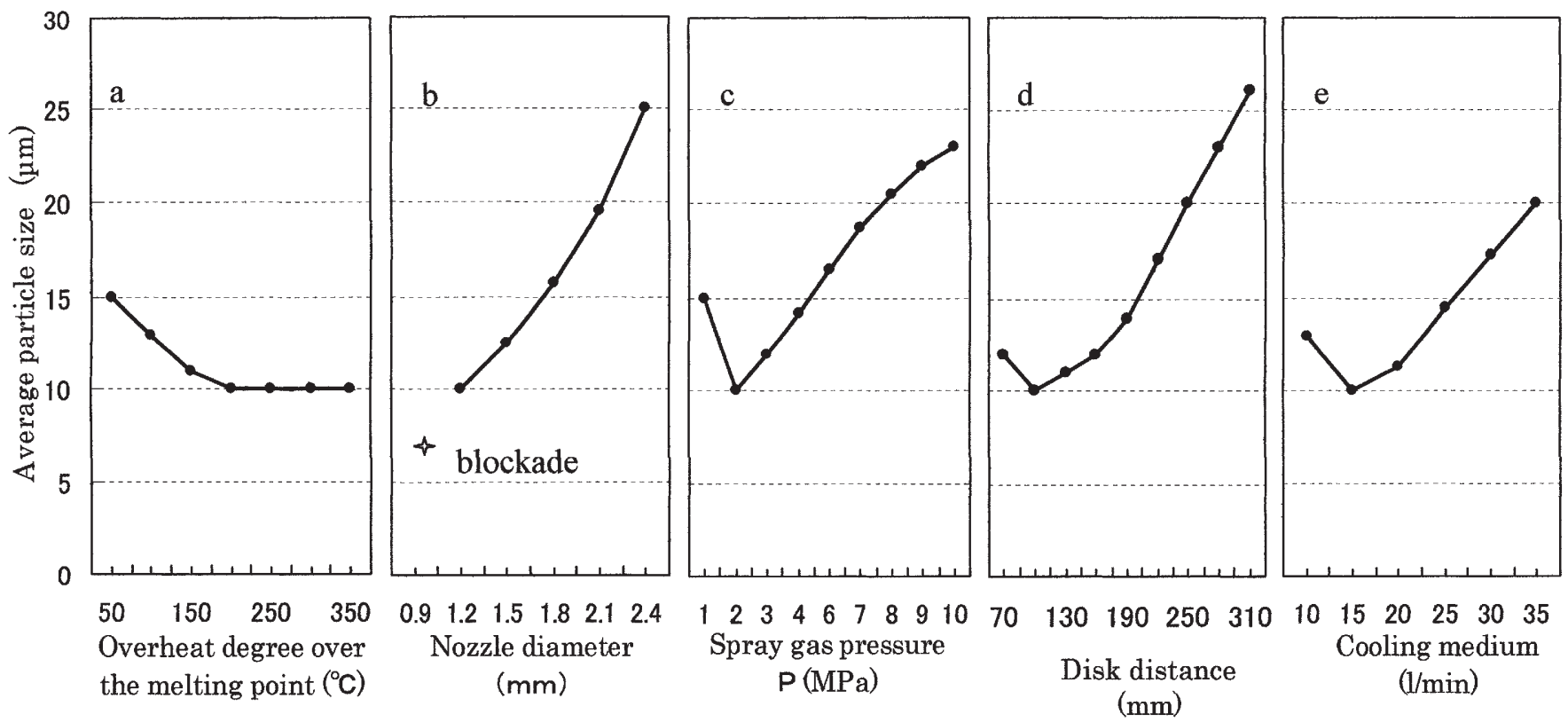

Fig.5 Influences of various controlling parameters on average particle size for $\mathrm{Cu}$ liquid.

いことが分かった. また, 噴霧ガス圧力を一定とした場合, 溶 湯ノズルからの溶湯流の断面積或いは溶湯流量が大きくなる ほど, 作製粉末の粒度分布は粗い粒径側に移行することが知 られている. Fig.5bに示す結果はノズル直径が小さすぎると, 閉塞が激しいので, $1.2 \mathrm{~mm}$ の場合に粒径は最も小さくなり, その平均值は $10 \mu \mathrm{m}$ であった.

\section{2 噴霧ガス圧力}

噴霧ガス圧力と粒子サイズの関係を Fig.5cに示す．噴霧ガ 又圧力が $2 \mathrm{MPa}$ 近傍で粒径は最も小さくなっている. 圧力が さらに高くなると，粒径は逆に大きくなる．この原因は，一 定のガス噴霧圧力で溶湯流量が多くなると, 衝突粉研の効率 が悪くなるためである，平均粒径も大きな粒径側に移行し， 堆積しやすくなるためと考えられる。一方，噴霧ガス圧力を 高くすれば，粉末は凝固しやすく，回転ディスクに衝突する までの未凝固粒子数が少なくなるため, 回転ディスクの役割 も小さくなる，逆に，低ガス噴霧力による粒子の飛翔速度の 減衰は速くなるため, 粉碎時の衝撃力は低下し, 粒径は大き くなることが分かった。

\section{3 回転ディスクの設置距離}

回転ディスクの設置距離は，Fig.5dに示すように溶湯ノズ ル直下の $100 \mathrm{~mm}$ が最適であり，平均粒径は $10 \mu \mathrm{m}$ となった. 設置距離を長くすると，凝固粒子の割合が増大し，粒子も粗 くなる.

\section{4 冷却媒体}

回転ディスクの表面温度の上昇を抑えるため, 冷却水を 使った. 水の流量と平均粒径の変化を Fig.5eに示す, 平均粒 径は $15 \mathrm{~L} / \mathrm{min}$ の流量で最小の $10 \mu \mathrm{m}$ となった. 水の流量が多 くなると，粒径は大きくなる. 冷却水の流量により回転ディ スクの温度上昇を抑えているが，冷却水を流しすぎると，周

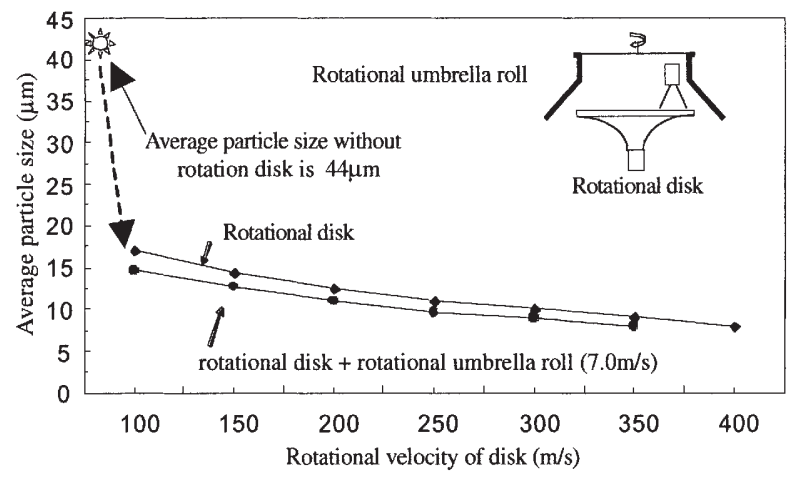

Fig.6 Pulverization effect caused by rotational disk and rotational umbrella roll. Relation between average particle size and rotational velocity of disk for $\mathrm{Cu}$ liquid.

囲の環境に水分が多くなり，粒子が冷却されやすくなる，そ のような状態では, 溶融, 半溶融の粒子が少なくなり, 平均 粒径は大きくなる. 上記の状況に基づいて最適な条件を選ぶ ことが重要である.

3.5 ディスク回転速度

Fig.6に示すように, ディスクの回転速度が速いほど, 粉末 の平均粒径は小さくなる. 回転速度を $250 \mathrm{~m} / \mathrm{s}$ にした場合, 平 均粒径注 $10 \mu \mathrm{m}$ となった。 また，末凝固粒子は逆方向に回転 している傘ロールに衝突する時, さらに粉砕され，2段階の 回転ディスクに比べて平均粒径がさらに1〜 3 $\mu \mathrm{m}$ 小さくなる ことが分かった．本研究では回転隶ロールの回転速度は 7.0 $\mathrm{m} / \mathrm{s}$ と一定にした. 粉碎エネルギーとしての衝撃力は回転 ディスクの回転速度に支配されている. 回転速度が速いほど 衝撃力が強くなり，得られる粉末の平均粒径は小さくなる. 
さらに, 粉砕粒子は遠心力により飛ばされ, 堆積せずに平滑 な衝突面を保持することができる.さらに, 高速回転ディス クでは一回転中に当たる溶湯量は少なくなり, 粉末の連結や 凝集 ${ }^{16,17)}$ の可能性は低くなることが分かった. Fig.7a惊速 回転ディスクにより溶湯粉末が衝突した時, 回転ディスクの 表面に堆積する方法の変化による変形挙動を示している. 衝 突の瞬間に粒子が引張られて長い帯尾状になっている. 粉砕 粒子像はFig.7cに示すようにロケット状や魚骨状などの形状 を呈している. 帯尾状, ロケット状及び魚骨状などの部分は 飛散してから微粉末になったと推察される. Fig.7bに示した 拡大写真は未凝固粒子が完全に粉砕されたものである. 明瞭 に観察された衝突瞬間像はガスアトマイズ後の未凝固粒子が 回転ディスクにより再粉砕できることを証明しており, 多段 階粉砕方法の有用性を示している.

一方, ガスアトマイズで粉砕された粒子が回転ディスク の表面に高速で衝突する瞬間では大部分が半溶融や溶融状態 を保持している. 回転ディスクの表面は極めて厳しい機械的, 熱的な環境にあり, 溶湯が衝突した回転ディスクの表面は損 傷を受けやすい. 損傷が起こると粒子は衝突体の表面から離 脱しにくくなる. その結果, 衝突体の表面に粒子が付着して 堆積する. 堆積防止法として, 高速回転による遠心力の利用, 冷却媒体の使用および連続的な表面クリーニング法などが有 効である. 冷却媒体には水, 油, 有機溶剤, 低沸点の液化ガ スなどを使用した。

3.6 粉末の性質

3.6.1 粒径と形状

Fig.8aに作製した粉末の粒度分布を示す. 平均粒径は約 10 $\mu \mathrm{m}$ であり, シャープな分布をもっている.また, Fig.8bのSEM 像に示すように，粉末粒形は注济球状であった。一般に凝固 時間が長くなれば, 表面張力により球状になりやすくなるが,
多段階急冷粉砕法では急速凝固しても球状粒子を生成できる 特長を持っているが, これは回転体の特異な効果に基づいて いる.この機構として, 衝突の瞬間に回転ディスクと回転卒 ロールは粒子にせん断力を加えながら遠心力を負荷できる.
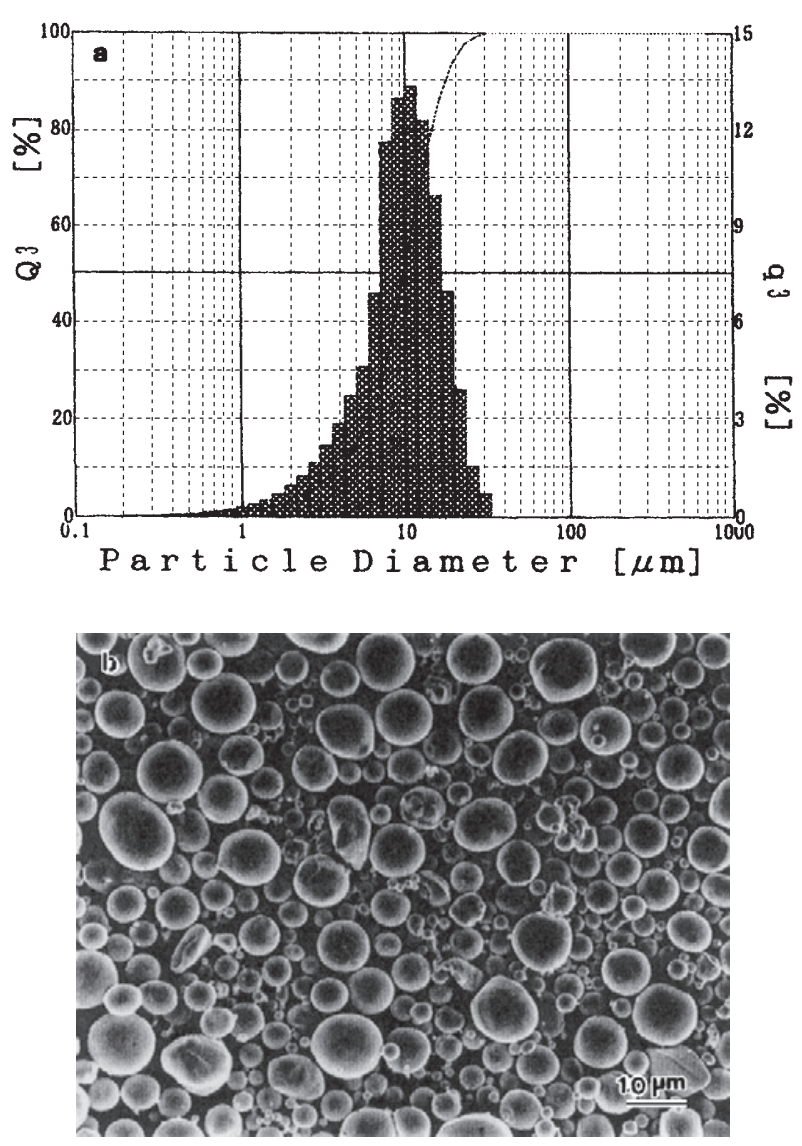

Fig.8 (a) Particle size distribution of Cu powder. (b) SEM showing the as-prepared $\mathrm{Cu}$ powders.
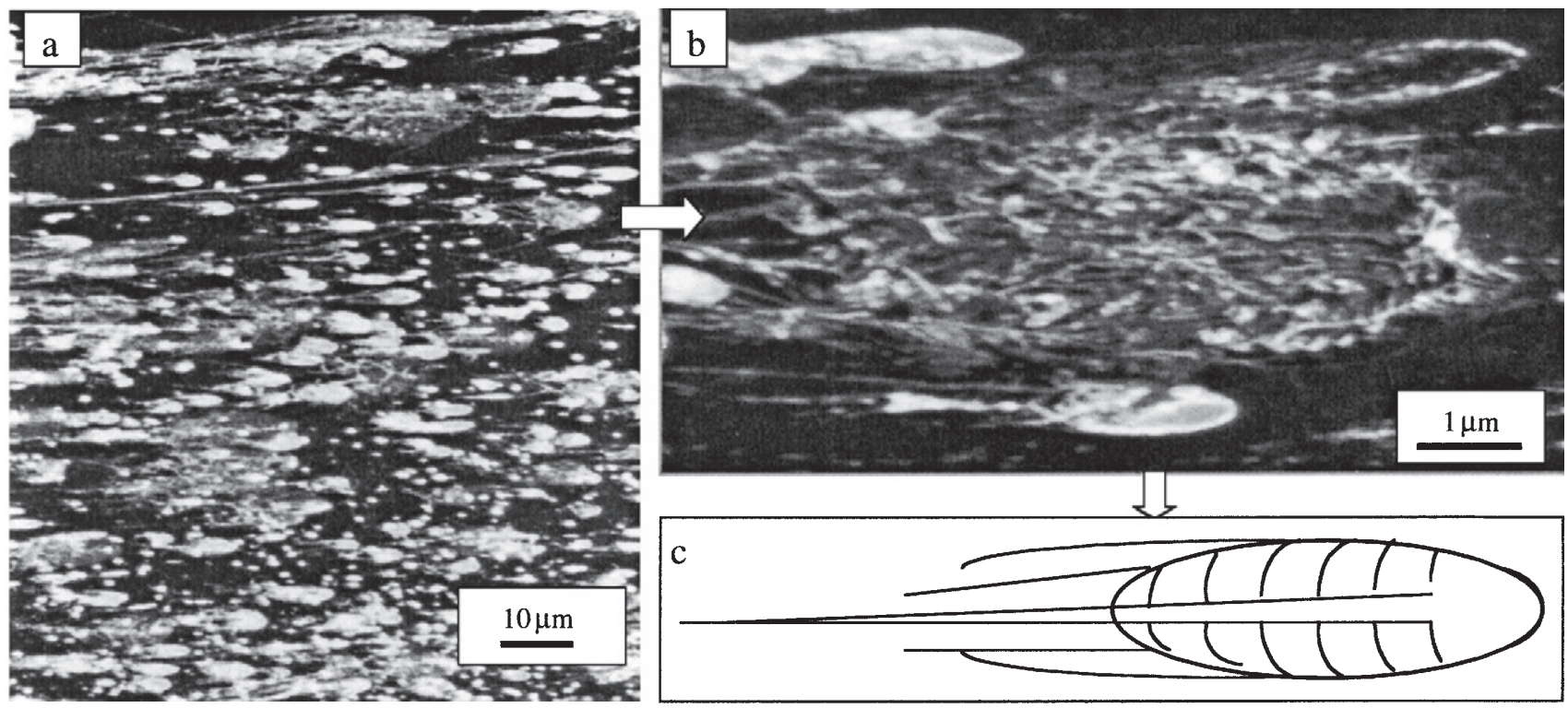

Fig.7 (a) Micrograph revealing crushed trace of Cu powder with a rotational disk. (b) Enlarged micrograph of (a). (c) Illustration image of (b). 
Table 1 Size of various metallic powders produced by gas atomization and multistage pulverization method.

$(\mu \mathrm{m})$

\begin{tabular}{|c|c|c|}
\hline Alloy & $\begin{array}{c}\text { Gas } \\
\text { atomization } \\
\text { method }\end{array}$ & $\begin{array}{c}\text { Multi-stage } \\
\text { rapid cooling } \\
\text { pulverization } \\
\text { method }\end{array}$ \\
\hline $\mathrm{Cu}$ & 42 & 10 \\
\hline $\mathrm{Al}$ & 38 & 7 \\
\hline $\mathrm{Co}$ & 44 & 10 \\
\hline $\mathrm{Ni}$ & 45 & 10 \\
\hline $\mathrm{Sn}$ & 37 & 8 \\
\hline $\mathrm{Ag}$ & 44 & 10 \\
\hline $\mathrm{SUS} 304$ & 45 & 11 \\
\hline (Fe-9.5Si-5.5Al) & 46 & 11 \\
\hline Fe-3.5C-2.7Si-0.4B & 43 & 10 \\
\hline
\end{tabular}

Table 2 Powder size and oxygen content of $\mathrm{Fe}-9.5 \mathrm{Si}-5.5 \mathrm{Al}$ (mass\%) alloy powder produced by various production methods.

\begin{tabular}{|c|c|c|}
\hline Production method & $\begin{array}{c}\text { Average particle } \\
\text { size } \\
(\mu \mathrm{m})\end{array}$ & $\begin{array}{c}\text { Oxygen } \\
\text { content } \\
(\mathrm{ppm})\end{array}$ \\
\hline Water atomization & 9.87 & 2250 \\
\hline Gas atomization & 10.4 & 183 \\
\hline $\begin{array}{c}\text { Multistage } \\
\text { pulverization }\end{array}$ & 10.2 & 220 \\
\hline
\end{tabular}

粒子はまず衝撃力により粉砕され，回転ディスクから遠心力 を受けて, 回転ディスクの接線方向へ自転しながら飛散する. 自転している粒子は気流の抵抗で最小の表面積を保持使用之 するために，球状になると考えられる，さらに，粒子が傘ロール に衝突して粉砕され，未凝固粒子を捕捉して再粉砕すること により, 微細粒子が高効率に得られた各試料の単一アトマイ ズ法と多段階粉砕法により作製した粉末の平均粒径をTable 1 にまとめている. 多段階粉砕法が単一ガスアトマイズ法より も粉末径を顕著に小さくできることが分かった.

3.6.2 粉末の表面酸化

多段階急冷粉砕法, 水アトマイズ法, ガスアトマイズ法に よりそれぞれ作製された Fe-9.5 Si-5.5 Al 合金粉末は篩で平均 粒径 $10 \mu \mathrm{m}$ くらいの粉末を選択し, 酸化度を測定した. その 結果はTabel 2に示した. 多段階急冷粉研法により作製した粉 末は $20 \mathrm{~L} / \mathrm{min}$ の冷却水を流しても, 酸化度がガスアトマイズ 粉末に比べて少し高いが, 水アトマイズ粉末より遥かに低い ことが分かった.酸化度が低いのは急速凝固されているため, 粒子表面での酸化膜の生成が充分に進行しなくなるためであ

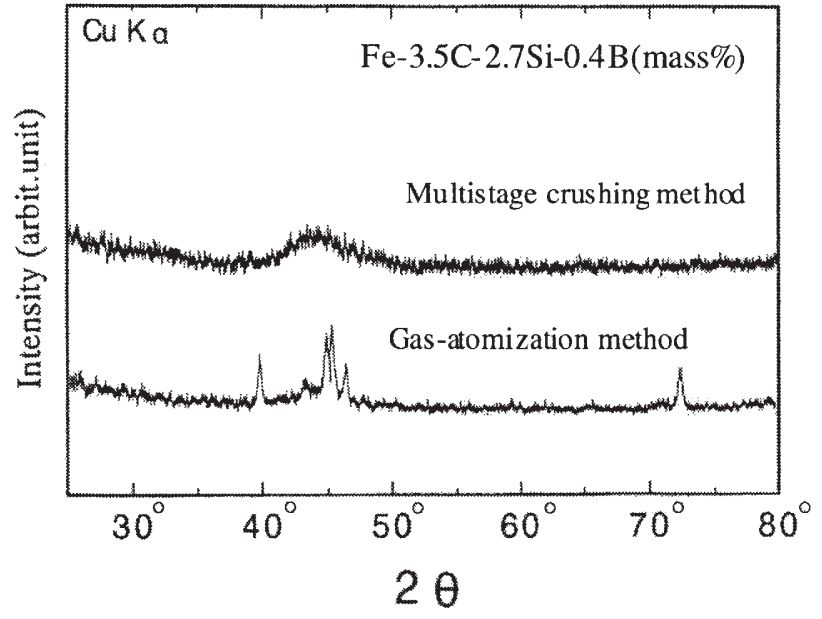

Fig.9 X-ray diffraction patterns of the Fe-3.5C-2.7Si-0.4B (mass\%) alloy by Multistage crushing method and Gasatomization method.

り, いわゆる急冷効果の結果と考えている.

\section{6 .3 急冷効果}

アモルファス相が生成できる Fe-3.5C-2.7Si-0.4B (mass\%) 合金 ${ }^{15)}$ を用いて粉末を作製した。一般のガスアトマイズ方法 で作製した粉末と多段階粉砕法で作製した粉末のX線回折図 形をFig.9に示した.一般のガスアトマイズ粉末には結晶相の 回折ピークがはっきり見られるが, 多段階粉砕粉末はアモル ファス相となっており, 粉末が充分に高い急冷速度で生成し たことを証明している.すなわち, 粉砕された微細粉末では 粗大粉末より熱が散発しやすく, 急冷効果が高まり, アモル ファス相やナノ結晶などの急冷組織の生成が容易になったと 考えられる.

\section{4 ま とめ}

多段階粉砕技術を開発し, 急速凝固組織を有する球状微細 粉末の高効率生産を目指した. 形成機構と各影響因子の関係 を詳細に調べた結果，次のことが明らかになった。

(1) 未凝固粒子を捕捉して高速回転ディスクの衝撃力で再粉 砕する機構が球状微粉末の作製に有効であることを見出 した.

(2) 回転ディスクを溶湯ノズル直下 $100 〜 250 \mathrm{~mm}$ に設置する ことにより, 大部分の粒子は溶融状態を保持しているこ とが計算及び実験方法により明らかになり，その利用に より分かった. 平均粒径 $10 \mu \mathrm{m}$ の $\mathrm{Cu}$ の微粉末が作製でき ることを確認した.

(3) 球状粉末が多く得られた理由として, 粉砕された液滴は 回転ディスクの接線方向へ自転しながら飛散するが，そ の際, 気流の抵抗を最小にしようとするために, 表面積を 最小にするためであると考えた.

(4) 粉砕された微細粉末は粗大粉末より熱を散発しやすく, アモルファスやナノ結晶相などの急速凝固組織が得られ ることが分かった。 
(5) ガス圧力, 溶湯流量, 過熱温度, 回転衝突体までの距離, 冷却媒体などの因子は粉末の粒径と形状に影響を及ぼし ており, 条件を最適化することにより, 制御できることが 分かった.

多段階粉砕技術は, 単一アトマイズ法に比べ, 高速で飛翔 凝固中の粒子のエネルギーを利用して, 急速凝固組織を有す る平均粒径 $10 \mu \mathrm{m}$ 以下の微細球状粉末を作製する新しい製造 方法と位置づけられる.

本技術はすでに大手企業において年産約 600 トン以上の非 鉄合金球状微細粉末の生産技術として実用されている.今後, 種々な金属合金粉末の製造に実用化されるものと確信している.

\section{文献}

1) R.H.Tanaka: Shinsozai/shikinzoku and saishinseizou • Kakougijutu, (1988)322-323.

2) JIM: Metal Data Book, Kaiteidai3ban, (1993)261-264.

3) K.Minagawa and K.Halada: Production of metal fine Powder, Patent No.3511082.

4) Takada and Kawai: "Effect of Delubricating Conditions on Dimensional Change in Sintering of Fe-Based Powder Compacts", J. Jpn. Soc. Powder Powder Metallurgy, 41 (1998) 1150-1156.

5) H.Shingu and K.Kobayashi: "Rapid Solidification of Light
Metals", Journal of Japan Institute of Light Metals, 31 (1981) 194-496.

6) H.Shingu: "Production and property of fine powders", J. Jpn. Soc Powder Powder Metallurgy, 46(1999) 1234.

7) J.M.Wentzell: method for powdering metals, U.S.patent 3510 546.

8) W. M.Gardiner: electrolyte for storage batteries, U.S.patent 1 389750.

9) A.R.Kaufmann: Method and appearatus for making powder, U.S.patent 3099041.

10) R.Paul: Apparatus for producing metal powder, U.S.patent 4 078873.

11) H.Miura, K.Takagi, Translation and R.M.German: Powder Metallurgy Science, (1996)125-156.

12) JSME: Heat Transfe,r Kaiteidai3ban, (1980) 43.

13) E.Gutierrez-Miravete, E.J.Lavernia, G.M.Trapaga, J.Szekely and N.J.Grant: "A Mathematical Model of the Spray Deposition, Process", Metall Trans, 20A(1989)71-73.

14) T.Fukuda: "Gas Velocity Distribution for a Confined-type Gas Atomization Nozzle", Iron and steel, 82(1996)635-640.

15) A.Inoue and X.M.Wang: "Bulk Amorphous FC20(Fe-C-Si) Alloys with Small Amounts of B and Their Crystallized and Mechanical Properties", Acta mater, 48(2000)1383-1395. 